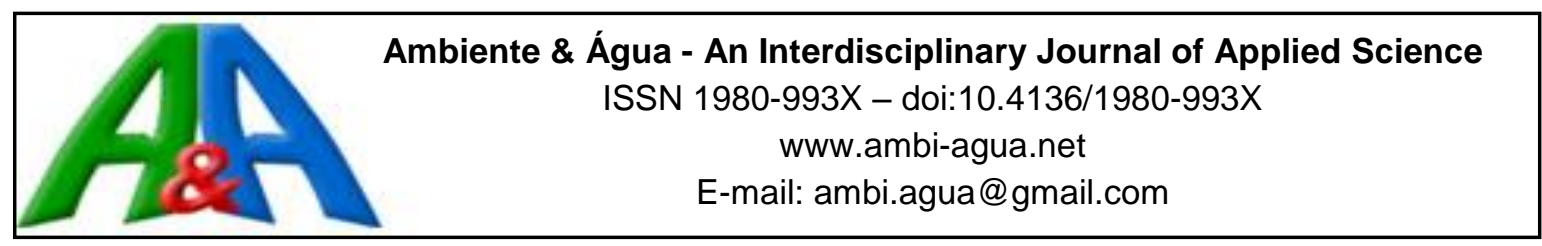

\title{
Biomonitors to evaluate the toxic potential of urban solid waste landfill leachate
}

ARTICLES doi:10.4136/ambi-agua.2326

Received: 06 Sep. 2018; Accepted: 18 Dec. 2018

\author{
Catiele Vieira1 $^{1 D}$; Annette Droste ${ }^{2 *(D)}$ \\ ${ }^{1}$ Universidade FEEVALE (FEEVALE), Novo Hamburgo, RS, Brasil \\ Instituto de Ciências da Saúde (ICS). E-mail: catyele_2003@hotmail.com \\ ${ }^{2}$ Universidade FEEVALE (FEEVALE), Novo Hamburgo, RS, Brasil \\ Programa de Pós-graduação em Qualidade Ambiental. E-mail: annette@ feevale.br \\ *Corresponding author
}

\begin{abstract}
The accentuated increase in the production of solid urban waste (SUW) and the consequent accumulation of leachate in landfills increase the risk of environmental contamination. Biomonitors are used to assess the toxicity of pollutants on living organisms. In this study, the pollutant potential of leachate from SUW from a deactivated landfill was evaluated by bioassays with Lactuca sativa L. and Lycopersicon esculentum Mill., and the relationship between chemical characteristics of the effluent and biological parameters was analyzed. The effluent was tested in its raw form and diluted in distilled water at concentrations of 75 and $50 \%$. The percentage of germination, root growth (RG), mitotic index (MI), chromosomal abnormalities index (CAI), and micronuclei frequency (MCN) were analyzed. In the presence of effluent, germination and MI decreased, while RG, CAI and MCN frequencies increased in relation to the negative control (distilled water) for both species. Lead, iron and zinc presented negative relation with seed germination for both species, with RG of $L$. sativa and MI of $L$. esculentum, as well as a positive relation with MCN frequency in the studied species. Because of its larger chromosomes, L. sativa is a more suitable biomonitor of SUW leachate toxicity than L. esculentum. Even though the landfill is deactivated, it is necessary to treat this effluent, in order to minimize environmental impacts.
\end{abstract}

Keywords: bioassay, effluent, toxicity.

\section{Biomonitores para avaliação do potencial tóxico do lixiviado de aterro de resíduos sólidos urbanos}

\section{RESUMO}

O aumento acentuado da produção de resíduos sólidos urbanos (RSU) e o consequente acúmulo de lixiviado em aterros potencializam o risco de contaminação do meio ambiente. Biomonitores são utilizados para avaliação da toxicidade dos poluentes sobre os organismos vivos. Neste estudo, foram avaliados o potencial poluidor do lixiviado de RSU de um aterro desativado por bioensaios com Lactuca sativa L. e Lycopersicon esculentum Mill. e a relação entre características químicas do efluente e os parâmetros biológicos analisados. O efluente foi testado na sua forma bruta e diluído em água destilada, nas concentrações de 75 e $50 \%$. Foram 
analisados o percentual de germinação, o crescimento radicular (CR), os índices mitótico (IM) e de anomalias cromossômicas (IAC), e a frequência de micronúcleos (MCN). Na presença do efluente, a germinação e o IM diminuíram, enquanto que o CR, IAC e a frequência de MCN aumentaram em relação ao controle negativo (água destilada) para ambas as espécies. Chumbo, ferro e zinco apresentaram relação negativa com a germinação das sementes de ambas as espécies, com o CR de L. sativa e com o IM de L. esculentum, além de uma relação positiva com a frequência de MCN nas espécies estudadas. L. sativa, por apresentar cromossomos maiores, é uma biomonitora de toxicidade de lixiviado de RSU mais adequada do que $L$. esculentum. Mesmo que o aterro esteja desativado, é necessário o tratamento deste efluente, com vistas a minimizar os impactos ambientais.

Palavras-chave: bioensaio, efluente, toxicidade.

\section{INTRODUCTION}

Population growth, together with technological development and increased consumption, lead to a rise in solid urban waste (SUW). In Brazil, the generation of SUW in 2016 totaled approximately 78.3 million tons (ABRELPE, 2016). The need for large expanses of land for final waste disposal and the possibility of environmental contamination make SUW management a major challenge for city administration (Rosa et al., 2017).

Landfills remain the most common SUW disposal practices, due to simple execution and relatively low cost (Yang et al., 2014). Landfills can be classified as sanitary, controlled and dumps. Sanitary landfills employ technology to minimize the environmental impact and possible human health risks, using things like composite liners that act as a low-permeable barrier, preventing liquid from leaching. At controlled landfills, the waste is simply covered with earth, with no leachate or biogas collection or processing. At dumps, the waste is left exposed on the ground (IBAM, 2001).

According to the most recent outlook on solid waste in Brazil, from 2016, conducted by the Brazilian Association of Public Cleaning and Special Waste Companies (ABRELPE), of all the waste collected in Brazilian municipalities, $58.4 \%$ is sent to sanitary landfills and $41.6 \%$ to controlled landfills and dumps (ABRELPE, 2016). This is despite Law 12,305/2010, which instituted the National Policy on Solid Waste, determining an end to controlled landfill and dump activities, as these means of disposal are considered incompatible with environmental protection. A maximum period of four years from the date of sanctioning was established for replacement with sanitary landfills.

Leachate, the byproduct resulting from the breakdown of solid waste, calls for closer attention due to its variability and the complexity in treating it, not to mention the myriad environmental impacts it can cause. Leachate can contain high levels of metals, suspended particles and organic matter. Leaching occurs in operating landfills, but also once they have been deactivated, as the organic matter continues to degrade and breakdown (Rosa et al., 2017).

Characterizing the leachate is an important factor in establishing a strategy to effectively manage it (El-Fadel et al., 2002), as the chemical composition tends to vary greatly (Budi et $a l ., 2016)$. The characteristics depend on the type of deposited waste, the means of disposal, management and length of time the landfill has existed. They are also greatly influenced by meteorological factors, among which rainfall volumes and air temperature are important (ElFadel et al., 2002). Due to the highly soluble substances and toxic composites, beside soil contamination, leaching may lead to the contamination of groundwater and aquifers in areas surrounding landfills, negatively impacting the environment and public health (Rosa et al., 2017). CONAMA Resolution 397/2008 of Brazil's National Council on the Environment (CONAMA, 2008) establishes the conditions and standards for disposing of this class of effluents.

Rev. Ambient. Água vol. 14 n. 2, e2326 - Taubaté 2019 
Leachate toxicity tests can be conducted by means of bioassays using plant species sensitive to toxicity of complex composites, although studies are scarce (Silva et al., 2015; Budi et al., 2016). Among the leading species for conducting toxicity bioassays evaluating seed germination, root growth, cell division and chromosome behavior and structure organization are Lactuca sativa L. (lettuce) and Lycopersicon esculentum Mill. (tomato), as they constitute species sensitive to toxic agents and germinate rapidly, while are also easily found in stores throughout the year at a low cost (Silva et al., 2015).

Within this context, the study proposed the following objectives: (a) to assess the toxic potential of SUW leachate in a deactivated controlled landfill by means of bioassays using $L$. sativa and L. esculentum; (b) to identify the biomonitoring organism and biological parameter most suited to detecting effluent toxicity; (c) to verify the relation between the physical and chemical properties of the leachate and the data obtained for biological parameters.

\section{MATERIALS AND METHODS}

\subsection{Deactivated controlled landfill}

The SUW landfill, occupying an area of $4,750 \mathrm{~m}^{2}$, is located in a municipality with a population of 22,514 inhabitants (IBGE, 2017), located in the Metropolitan Region of Porto Alegre, the capital of Rio Grande do Sul state, in the south of Brazil. The landfill remained activated for 13 years until 2005.

\subsection{Collection and analysis of leachate physical and chemical parameters}

A 5-liter sample of leachate was collected at the landfill in January 2017. Collection, storage, preservation and transport of the leachate sample were in full accord with criteria established by the Standard Methods for the Examination of Water and Wastewater (APHA et al., 2012). The following parameters were noted: $\mathrm{pH}$, temperature, electric conductivity (EC) and dissolved oxygen (DO) with the aid of the AK88-ASKO ${ }^{\circledR}$ multi-parameter meter; biochemical oxygen demand $\left(\mathrm{BOD}_{5}\right)$, by manometry (SM 5210); chemical oxygen demand (COD), by titration ( $\mathrm{SM} 5220)$; ammoniacal nitrogen $\left(\mathrm{NH}_{3}-\mathrm{N}\right)$, by titration $\left(4500 \mathrm{NH}_{3}\right)$; nitrite $\left(\mathrm{NO}_{2}\right)$, through ultraviolet-visible spectroscopy ( $\left.\mathrm{SM} 4500 \mathrm{NO}_{2-}\right)$; nitrate $\left(\mathrm{NO}_{3}\right)$, through ultraviolet-visible spectroscopy ( $\mathrm{SM} 4500 \mathrm{NO}_{3}$ ) and concentrations of iron $(\mathrm{Fe})$, zinc $(\mathrm{Zn})$, lead $(\mathrm{Pb})$, cadmium $(\mathrm{Cd})$, nickel $(\mathrm{Ni})$ and copper $(\mathrm{Cu})$, by flame atomic absorption spectroscopy (SM 3111).

\subsection{Bioassays}

Bioassays were prepared in a laminar flow chamber in the laboratory. Leachate was used in its raw form ( $100 \%$ original concentration) and diluted in distilled water, at concentrations of $75 \%$ and $50 \%$. Distilled water was used as the negative control, and for positive control, the minimum inhibitory concentration of copper $\left(3 \mathrm{mg} \mathrm{L}^{-1}\right.$ of $\left.\mathrm{CuSO}_{4}\right)$ was used, equal to the lowest concentration of the metal able to inhibit root growth (Di Salvatore et al., 2008). Lactuca sativa and L. esculentum seeds were germinated in Petri dishes with a diameter of $9 \mathrm{~cm}$, containing a sheet of quantitative filter paper (GE Healthcare ${ }^{\mathrm{TM}}$ ) sterilized and moistened with $5 \mathrm{~mL}$ solution of the specified solutions (leachate concentrations and controls). Three dishes were prepared for each treatment and biomonitor, each containing fifteen seeds and sealed with plastic film. The dishes were kept at a temperature of $25 \pm 1^{\circ} \mathrm{C}$, for a 16 -hour photoperiod.

\subsection{Germination}

Germinated seeds in each dish were counted after two days of exposure to the treatments, according to Aguiar et al. (2016). Seeds showing evidence of root protrusion, visible without the aid of instruments, were considered germinated. The data were used to calculate the average of germinated seeds for each biomonitor in each treatment. 


\subsection{Root growth}

Root growth was assessed after seven days of exposure to the treatments (Carvalho et al., 2014) with the aid of a millimeter rule. Root lengths of five random seedlings per dish were measured, totaling 15 seedlings per treatment and biomonitor. Root length was measured from the hypocotyl of the seedling to the apical meristem of the root system, according to Gatti et al. (2004).

\subsection{Mitotic index, chromosomal abnormality index and micronuclei frequency}

Root tips were randomly removed from five seedlings from each Petri dish after two days of exposure, totaling 15 roots per treatment and organism. The tips were fixed in an ethanol: acetic acid $(3: 1 \mathrm{v} / \mathrm{v})$ solution for 24 hours at room temperature and then transferred to $70 \%$ ethanol at $4{ }^{\circ} \mathrm{C}$. Of the 15 roots removed per treatment, the meristem region of only 10 random roots were used. The remaining material was kept in reserve. To prepare the microscopic slides, the root tips were sequentially treated for 2 minutes in distilled water, then hydrolyzed for 6 minutes in $\mathrm{HC} 11 \mathrm{~N}$ and washed again for 2 minutes in distilled water. Microscopic slides were prepared according to Cuchiara et al. (2012). The hydrolyzed root tips were squashed on microscopic slides and stained with $2 \%$ aceto-orcein. The number of cells in mitosis and cells with chromosomal abnormalities, and the number of micronuclei (MCN) were counted at 500 cells per root through the scanning technique, using an optic microscope (Nikon Eclipse E200) at 400x magnification. The mitotic index (MI) was calculated using the formula $\mathrm{MI}=[$ (number of mitotic cells/total cells)100]. The chromosomal abnormalities index (CAI) was calculated by $\mathrm{CAI}=[($ number of cells with abnormality/total cells in division)100]. Micronuclei frequency was expressed as MCN/100 cells.

\subsection{Statistical analysis}

Data were subjected to the Shapiro-Wilk normality test and as they complied with assumption of normality, differences between the averages were analyzed by ANOVA, followed by the Duncan test. The relation between biological parameters and the metals $\mathrm{Pb}, \mathrm{Fe}$ and $\mathrm{Zn}$ was verified using the Pearson correlation coefficient. All statistical analysis was conducted using the SPSS program, version 20.0, at $5 \%$ probability.

\section{RESULTS AND DISCUSSION}

The COD value was three times greater than the $\mathrm{BOD}_{5}$ in the raw leachate sample (Table 1). $\mathrm{BOD}_{5}$ refers to the biodegradable organic mass, while COD refers to all the oxidizable matter in the effluent (CETESB, 2016). The $\mathrm{BOD}_{5} / \mathrm{COD}$ calculated for the raw leachate was 0.29 . Due to the $\mathrm{BOD}_{5} / \mathrm{COD}$ ratio, the landfill in the present study would be classified as moderately stable, according to the Solid Waste Association of North America (SWANA, 1997) classification. This ratio could be considered an indicator of the level of organic matter biodegradability, which diminishes over time (El-Fadel et al., 2002).

The leachate presented $\mathrm{pH}$ levels higher than 7 (Table 1). The $\mathrm{pH}$ variation over the years is linked to the $\mathrm{COD}$ and $\mathrm{BOD}_{5}$ values, with the $\mathrm{pH}$ starting at around 5.5 and increasing to around 8 within two years of the landfill initiating operations. An alkaline $\mathrm{pH}$ is usually found in landfills after depositing waste for 10 years (Farquhar, 1989), which would corroborate the findings of this study.

The electric conductivity (EC) value of the raw leachate sample was $1,562 \mu \mathrm{S} \mathrm{cm}^{-1}$ (Table 1), double the average found by Riguetti et al. (2015), which, when analyzing the toxicity of leachate from a sanitary landfill located in the state of Minas Gerais, Brazil, recorded an EC average of approximately $630 \mu \mathrm{S} \mathrm{cm}^{-1}$ in a period of one year. High EC indicates a large volume of ions present in the effluent. In general, levels above $100 \mu \mathrm{S} \mathrm{cm}^{-1}$ indicate environmental impacts (CETESB, 2016). 
Table 1. Physical and chemical characteristics of different leachate concentrations, with their respective detection limit.

\begin{tabular}{|c|c|c|c|c|c|}
\hline \multirow{2}{*}{ Parameters } & \multicolumn{3}{|c|}{ Leachate } & \multirow[t]{2}{*}{ Detection limit } & \multirow[t]{2}{*}{ CONAMA 397/2008 } \\
\hline & $100 \%$ & $75 \%$ & $50 \%$ & & \\
\hline $\mathrm{pH}$ & 7.22 & 7.26 & 7.35 & 2.00 & n.i. \\
\hline Temperature $\left({ }^{\circ} \mathrm{C}\right)$ & 17.8 & 16.8 & 16.5 & 0.0 & n.i. \\
\hline $\mathrm{BOD}_{5}\left(\mathrm{mg} \mathrm{O}_{2} \mathrm{~L}^{-1}\right)$ & 39 & 40 & 44 & 5.0 & n.i. \\
\hline $\mathrm{COD}\left(\mathrm{mg} \mathrm{O}_{2} \mathrm{~L}^{-1}\right)$ & 131 & 92 & 62 & 3.10 & n.i. \\
\hline $\mathrm{EC}\left(\mu \mathrm{S} \mathrm{cm}^{-1}\right)$ & 1,562 & 1,200 & 852 & 200 & n.i. \\
\hline $\mathrm{DO}\left(\mathrm{mg} \mathrm{L}^{-1}\right)$ & 3.2 & 5.9 & 7.4 & 0.0 & n.i. \\
\hline Ammoniacal nitrogen $\left(\mathrm{mg} \mathrm{L}^{-1}\right)$ & 36.3 & 28.2 & 18.1 & 5.0 & 20.0 \\
\hline Nitrite $\left(\mathrm{mg} \mathrm{L}^{-1} \mathrm{~N}\right.$ in $\left.\mathrm{NO}_{2}\right)$ & 0.289 & 0.206 & 0.225 & 0.002 & n.i. \\
\hline Nitrate $\left(\mathrm{mg} \mathrm{L}^{-1} \mathrm{~N}\right.$ in $\left.\mathrm{NO}_{3}\right)$ & 0.2516 & 0.2418 & 3.1063 & 0.0785 & n.i. \\
\hline $\mathrm{Fe}\left(\mathrm{mg} \mathrm{L}^{-1}\right)$ & 1.181 & 0.541 & 0.277 & 0.1414 & 15.0 \\
\hline $\mathrm{Zn}\left(\mathrm{mg} \mathrm{L}^{-1}\right)$ & 0.017 & 0.020 & 0.018 & 0.0095 & 5.0 \\
\hline $\mathrm{Pb}\left(\mathrm{mg} \mathrm{L}^{-1}\right)$ & 0.056 & 0.041 & 0.037 & 0.0112 & 0.5 \\
\hline $\mathrm{Cd}\left(\mathrm{mg} \mathrm{L}^{-1}\right)$ & n.d. & n.d. & n.d. & 0.0075 & 0.2 \\
\hline $\mathrm{Ni}\left(\mathrm{mg} \mathrm{L}^{-1}\right)$ & n.d. & n.d. & n.d. & 0.0643 & 2.0 \\
\hline $\mathrm{Cu}\left(\mathrm{mg} \mathrm{L}^{-1}\right)$ & n.d. & n.d. & n.d. & 0.0316 & 1.0 \\
\hline
\end{tabular}

n.i. $=$ not informed by CONAMA Resolution 397/2008.

The concentration of ammoniacal nitrogen was $36.3 \mathrm{mg} \mathrm{L}^{-1}$, considered high, according to CONAMA Resolution 397/2008 (20.0 $\left.\mathrm{mg} \mathrm{L}^{-1}\right)$, with this constituting the only parameter found over the limit permitted in legislation (CONAMA, 2008). To the contrary, the concentrations of DO and metals detected were low (Table 1). In the early years, young landfills produce a leachate with greater pollutant potential, due to the presence of metals in higher concentrations. The older the landfill, the higher the index of ammoniacal nitrogen due to hydrolysis and fermentation, and the lower the concentrations of organic matter and metal ions (Renou et al., 2008). In the raw leachate, these ions are associated with organic and inorganic colloidal particles and in the form of complexes. The reductive conditions of the effluent and the alkaline $\mathrm{pH}$ lead to metal ions being complexed in the form of sulfides, sulfates, carbonates and oxyhydroxides and also precipitated in insoluble composites considerably reducing bioavailability of the metals (Riguetti et al., 2015).

At its maximum concentration, leachate reduced the germination capacity of $L$. sativa, with $86.6 \%$ of the seeds germinating. Comparably, the raw leachate from a deactivated sanitary landfill located in the region of Vale dos Sinos, in the state of Rio Grande do Sul, Brazil, also presented toxicity for this species, with $90 \%$ of the seeds germinating (Klauck et al., 2015). Lycopersicon esculentum seeds appeared to be more sensitive than the L. sativa seeds, with the leachate reducing the number of germinated seeds with an increase in concentration and completely inhibited germination at a $100 \%$ concentration (Table 2 ).

This study recorded a significant increase in root length in the presence of leachate when compared to the controls in both plant species (Table 2). The lower concentration of leachate $(50 \%)$ led to a higher average in root growth in L. sativa $(5.70 \mathrm{~cm})$ and $L$. esculentum $(8.28$ $\mathrm{cm})$. Rodrigues et al. (2013) also noted root growth stimulation for L. sativa when analyzing the water from an urban stream located in the municipality of Alfenas, in the state of Minas Gerais, Brazil, and attributed this result to a greater offer of nutrients provided by the organic load in water. 
Table 2. Values (average \pm standard deviation) of germination percentage (GM), root growth (RG in $\mathrm{cm})$, mitotic index (MI), chromosomal abnormality index (CAI) and micronuclei frequency (MCN) in Lactuca sativa and Lycopersicon esculentum exposed to leachate and control treatments.

\begin{tabular}{|c|c|c|c|c|c|c|}
\hline \multirow{3}{*}{\multicolumn{2}{|c|}{ Parameters }} & \multicolumn{5}{|c|}{ Treatments } \\
\hline & & \multicolumn{3}{|c|}{ Leachate } & \multicolumn{2}{|c|}{ Controls } \\
\hline & & $100 \%$ & $75 \%$ & $50 \%$ & $\mathrm{H}_{2} \mathrm{O}$ & $\mathrm{CuSO}_{4}$ \\
\hline \multirow{5}{*}{$\begin{array}{l}L . \\
\text { sativa }\end{array}$} & GM & $86.66 \pm 6.66 \mathrm{c}$ & $93.33 \pm 0.00 \mathrm{abc}$ & $95.55 \pm 3.84 \mathrm{ab}$ & $100.00 \pm 0.00 \mathrm{a}$ & $88.88 \pm 3.84 b c$ \\
\hline & RG & $4.24 \pm 0.68 \mathrm{c}$ & $4.99 \pm 0.85 \mathrm{~b}$ & $5.70 \pm 0.92 \mathrm{a}$ & $4.11 \pm 1.08 c$ & $2.00 \pm 0.98 \mathrm{~d}$ \\
\hline & MI & $4.98 \pm 1.13 \mathrm{~b}$ & $5.36 \pm 1.41 \mathrm{~b}$ & $5.14 \pm 1.29 b$ & $9.58 \pm 1.79 \mathrm{a}$ & $4.58 \pm 0.52 b$ \\
\hline & CAI & $28.04 \pm 11.48 b$ & $25.68 \pm 7.69 b$ & $13.94 \pm 5.72 b$ & $13.94 \pm 5.72 \mathrm{a}$ & $30.93 \pm 8.05 b$ \\
\hline & $\mathrm{MCN}$ & $4.64 \pm 1.23 \mathrm{c}$ & $3.56 \pm 1.35 \mathrm{~b}$ & $3.06 \pm 0.83 \mathrm{ab}$ & $2.38 \pm 0.51 \mathrm{a}$ & $4.70 \pm 1.40 \mathrm{c}$ \\
\hline \multirow{5}{*}{$\begin{array}{l}\text { L. } \\
\text { esculentum }\end{array}$} & GM & 0 & $24.44 \pm 16.77 \mathrm{c}$ & $51.11 \pm 13.87 \mathrm{~b}$ & $88.88 \pm 10.18 \mathrm{a}$ & $66.66 \pm 6.66 \mathrm{ab}$ \\
\hline & RG & n.a. & $7.94 \pm 1.44 a b$ & $8.28 \pm 1.15 \mathrm{a}$ & $6.83 \pm 1.41 \mathrm{~b}$ & $5.67 \pm 1.95 \mathrm{c}$ \\
\hline & MI & n.a. & $2.74 \pm 0.66 \mathrm{c}$ & $4.24 \pm 0.54 b$ & $4.82 \pm 0.45 \mathrm{a}$ & $2.10 \pm 0.31 \mathrm{~d}$ \\
\hline & CAI & n.a. & $12.96 \pm 5.95 \mathrm{a}$ & $7.29 \pm 5.16 \mathrm{a}$ & $7.04 \pm 2.82 \mathrm{a}$ & $21.63 \pm 13.77 b$ \\
\hline & $\mathrm{MCN}$ & n.a. & $0.14 \pm 0.16 b$ & $0.04 \pm 0.08 \mathrm{a}$ & $0.00 \pm 0.00$ & $0.06 \pm 0.09 \mathrm{ab}$ \\
\hline
\end{tabular}

Averages followed by the same letter on the line do not differ significantly in accord with the Duncan test at $5 \%$ probability / n.a. $=$ not analyzed.

For both species studied, the MI was significantly lower in the different leachate concentrations and in the positive control than in the negative control (Table 2). In Allium cepa, besides recording negative effects from the leachate on the MI in five of the six municipal solid waste landfill sites analyzed in Southern Poland, a negative relation was noted between the physical and chemical quality of each leachate and their genotoxicity (Kwasniewska et al., 2012), which corroborates with the results obtained in this study with L. sativa and $L$. esculentum. Alterations of the mitotic index are considered good indicators of environmental pollution, especially in the assessment of substances with cytotoxic potential (Leme and MarinMorales, 2009).

In L. esculentum, CAI values in the leachate concentrations and in the negative control did not differ and were lower than those of the positive control. Lycopersicon esculentum chromosomes are smaller, as such, this characteristic complicated the analysis of chromosomal abnormalities for this plant species. Further, in the raw leachate treatment (100\%), the $L$. esculentum seeds did not germinate, as such, the comparison with other plant species is jeopardized. Lactuca sativa, on the other hand, showed significantly higher CAI values in leachate concentrations and in the positive control, when compared to the negative control (Table 2). Chromosomal abnormalities (CA) are changes that occur in the chromosome structure through the action of chemical and physical agents or can even occur spontaneously (Leme and Marin-Morales, 2009).

The quantified CA were constituted by $\mathrm{C}$-metaphase, isolated chromosome, or anaphase and telophase with bridges (Figure 1). A break down in the spindle apparatus is responsible for aneugenic alterations resulting from disturbances in spindle activity. The chromosomes are not correctly linked to the spindle and do not take on the correct position in the cell and, thus, they are spread throughout it internally instead. The chromosomal bridges are clastogenic alterations observed in anaphase and telophase and occur due to a loss of telomeres, the region responsible for guaranteeing chromosome protection and stability, preventing erroneous fusions and pairings (Leme and Marin-Morales, 2009).

The occurrence of MCN in L. esculentum was low, with the negative control not presenting them. In L. sativa, greater MCN frequency was noted, even registering $\mathrm{MCN}$ in the negative control $(2.38 \mathrm{MCN})$. The highest frequencies were found when plants were exposed to raw leachate (4.64 MCN) and the positive control (4.70 MCN). We may infer that the MCNs found 
in the negative control form spontaneously. For other treatments, the higher MCN frequency in relation to the control shows the toxic effect of leachate and $\mathrm{CuSO}_{4}$. The MCNs are tiny cell structures formed through chromosomal loss or chromosomal fragmentation caused by CA and also due to the structural alteration in the spindle apparatus fibers, which can be induced by genotoxic agents or even may be a result of spontaneous mutation (Kieling-Rubio et al., 2015).

The $\mathrm{CuSO}_{4}$ was shown to be a good positive control, as it was able to damage both plant species, observed by means of reduced germination and root growth, by the reduced number of cells in mitosis and also by the stimulation and increase of CA and MCN frequency (Table 2). Despite copper figuring as an essential micronutrient in plant development, in elevated concentrations it becomes toxic, inhibiting several plant metabolism processes (KabataPendias, 2011).

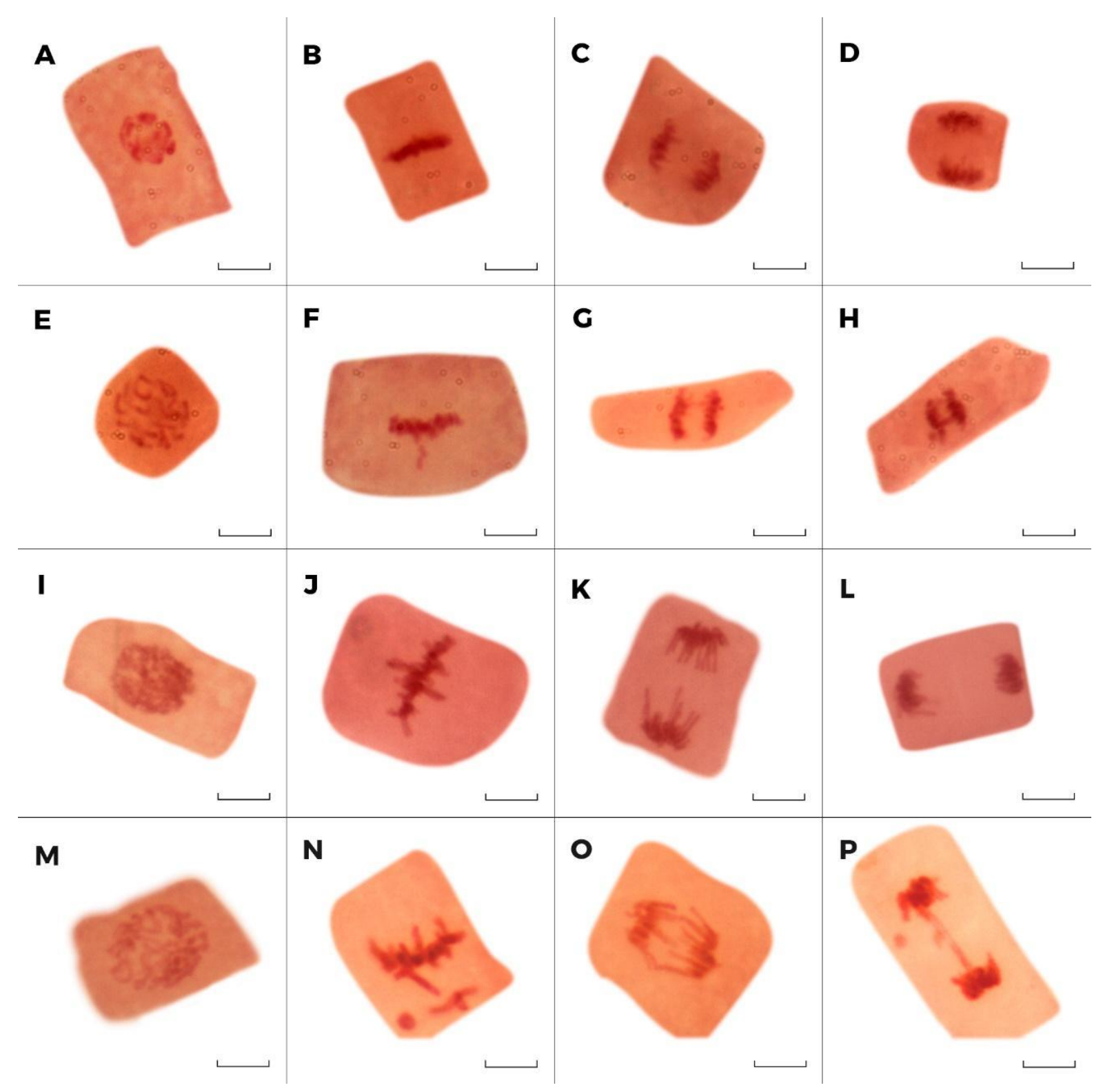

Figure 1. Chromosomes with and without abnormalities observed in Lycopersicon esculentum (A - H) and Lactuca sativa (I - P) root meristematic cells exposed to different leachate concentrations. (A and I) prophase; (B and J) metaphase; (C and $\mathrm{K}$ ) anaphase; (D and $\mathrm{L}$ ) telophase; (E and $\mathrm{M}) \mathrm{C}$-metaphase; $(\mathrm{F}$ and $\mathrm{N}$ ) metaphase with isolated chromosome; ( $\mathrm{G}$ and $\mathrm{O}$ ) anaphase with bridge; ( $\mathrm{H}$ and $\mathrm{P}$ ) telophase with bridge and MCN. Bar: $10 \mu \mathrm{m}$ 
L. esculentum germination and $\mathrm{MI}$ related negatively with $\mathrm{Pb}, \mathrm{Fe}$ and $\mathrm{Zn}(\mathrm{r}=-0.728$; $\mathrm{p}<0.001),(\mathrm{r}=-0,757 ; \mathrm{p}<0.001)$, respectively, while the frequency of MCN was positively related to the same metals $(\mathrm{r}=0.449 ; \mathrm{p}=0.013)$. In $L$. sativa, germination was also negatively related to $\mathrm{Pb}$ and $\mathrm{Fe}(\mathrm{r}=-0.720 ; \mathrm{p}<0.001)$. Root growth showed a negative relation with $\mathrm{Pb}(\mathrm{r}=-$ $0.571 ; \mathrm{p}<0.001)$ and $\mathrm{Fe}(\mathrm{r}=-0.585 ; \mathrm{p}<0.001)$, while the frequency of $\mathrm{MCN}$ related positively to $\mathrm{Pb}(\mathrm{r}=0.570 ; \mathrm{p}<0.001)$ and $\mathrm{Fe}(\mathrm{r}=0.582 ; \mathrm{p}<0.001)$. Despite being considered essential micronutrients in plant metabolism (Kabata-Pendias, 2011), when Fe and Zn are present in elevated concentration in the environment, they may induce the formation of micronuclei (Kieling-Rubio et al., 2015) and reduce germination and root growth (Wang et al., 2011). Lead does not play an essential role in plant metabolism and it is also considered one of the most toxic metals to them. Its toxic effects are chiefly related to fundamental biological process damage, such as photosynthesis, growth and mitosis (Kabata-Pendias, 2011). This metal may delay or inhibit plant germination, as described for wheat (Lamhamdi et al., 2011), while also interfering in root growth (Moraes et al., 2014). The relation found between the formation of $\mathrm{MCN}$ and $\mathrm{Pb}$ was also observed in Vicia faba root cells, with MCN frequency used as one of the parameters to determine the toxic potential of $\mathrm{Pb}$ (Pourrut et al., 2011). The reduction in cell division induced by $\mathrm{Pb}$ may be associated to this metal's link to the cell wall and membranes, increasing rigidity and defects in microtubule organization. As a result, malformation of the microtubules can lead to an increase in the number of chromosomal abnormalities (Jiang et al., 2014).

\section{CONCLUSIONS}

The physical and chemical results indicate that the controlled landfill is at the methanogenic stage. Based on the analysis of biological parameters in different leachate concentrations, one may conclude that the effluent presents potential toxicity for L. sativa and L. esculentum, as it reduced the germination percentage and the number of mitotic divisions in both plant species, while also promoting the formation of chromosomal abnormalities and micronuclei, especially in L. sativa. The rise in root growth may be associated with the volume of organic matter present in the effluent. Biological parameters that best responded to the effluent toxicity were seed germination and the number of mitotic divisions, along with MCN frequency for L. sativa. The reduced index of CA and MCN in L. esculentum may be associated with the small size of chromosomes in comparison with L. sativa, thus jeopardizing visibility. It is also possible to infer that both plant species demonstrated being efficient biomonitors of environmental quality by showing evidence of sensitivity to the analyzed variables. However, L. sativa showed a more significant treatment $\mathrm{x}$ response relation in all analyzed biological parameters, which allowed for a unique interpretation of the results from specific leachate treatments. The relation noted between germination, root growth, MI and MCN frequency indicated a negative influence on the species studied from $\mathrm{Pb}, \mathrm{Fe}$ and $\mathrm{Zn}$ present in the effluent. This relation reiterates the importance of associating physical and chemical analysis with an assessment of biological parameters, by means of assays using environmental quality biomonitors. Based on these findings, one may suggest that, even with a controlled SUW landfill deactivated for over a decade, there is a need to treat this effluent, with the goal of minimizing possible impacts on the environment.

\section{ACKNOWLEDGEMENTS}

The authors thank Universidade Feevale for the infrastructure and the Scientific Initiation Grant awarded to the first author. 


\section{REFERENCES}

ABRELPE. Panorama dos Resíduos Sólidos no Brasil 2016. São Paulo, 2016. Available in: http://www.abrelpe.org.br/Panorama/panorama2016.pdf. Access: 21 Mar. 2018.

AGUIAR, L. L.; VIEIRA, L. F. A.; DAVID, J. A. O. Evaluation of the toxic potential of coffee wastewater on seeds, roots and meristematic cells of Lactuca sativa L. Ecotoxicology and Environmental Safety, v. 133, p. 366-372, 2016. https://dx.doi.org/10.1016/j.ecoenv.2016.07.019

APHA; AWWA; WPCF. Standard methods for the examination of water and wastewater. Washington, 2012. $1360 \mathrm{p}$.

BUDI, S.; SULIASIH, A.; OTHMAN, M. S.; HENG, L. Y.; SURIF, S. Toxicity identification evaluation of landfill leachate using fish, prawn and seed plant. Waste Management, Viena, v. 55, p. 231-237, 2016. https://doi.org/10.1016/j.wasman.2015.09.022

CARVAlHO, W. P.; CARVAlHO, G. J.; ABBADE-NETO, D. O.; TEIXEIRA, L. G. V. Alelopatia de extratos de adubos verdes sobre a germinação e crescimento inicial de alface. Bioscience Journal, v. 30, n. 1, p. 11-11, 2014.

CETESB. Relatório de qualidade das águas superficiais. Apêndice D. Significado ambiental e sanitário das variáveis de qualidade das águas e dos sedimentos e metodologias analíticas e de amostragem. São Paulo, 2016. 46 p.

CONAMA. Resolução $n^{\circ}$ 397, de 03 de abril de 2008. Altera o inciso II do $\S 4^{\circ}$ e a Tabela X do $\S 5^{\circ}$, ambos do art. 34 da Resolução do Conselho Nacional do Meio AmbienteCONAMA no 357 , de 2005, que dispõe sobre a classificação dos corpos de água e diretrizes ambientais para o seu enquadramento, bem como estabelece as condições e padrões de lançamento de efluentes. Diário Oficial da União, Brasília, DF, 07 abril de 2008. Available in: http://www.mma.gov.br/port/conama/legiabre.cfm?codlegi $=459$ Access: 08 July 2018.

CUCHIARA, C. C.; BORGES, C. S.; BOBROWSKI, V. L. C. Sensibilidade de sementes de hortaliças na avaliação da qualidade da água em bioensaios. Revista Biotemas, v. 25, n. 3, p. 19-27, 2012. https://dx.doi.org/10.5007/2175-7925.2012v25n3p19

EL-FADEL, M.; BOU-ZEID, R.; CHAHINE, W.; ALAYLI, B. Temporal variation of leachate quality from pre-sorted and baled municipal solid waste with high organic and moisture content. Waste Management, v. 22, p. 269-282, 2002. https://dx.doi.org/10.1016/S0956053X(01)00040-X

FARQUHAR G. J. Leachate: production and characterization. Canadian Journal of Civil Engineering, v. 16, p. 317-325, 1989. https://dx.doi.org/10.1139/189-057

GATTI, A. B.; PEREZ, S. C. J. G. A.; LIMA, M. I. S. Atividade alelopática de extratos aquosos de Aristolochia esperanzae O. Kuntze na germinação e no crescimento de Lactuca sativa L. e Raphanus sativus L. Acta Botanica Brasilica, v. 18, n. 3, p. 459-472, 2004. https://dx.doi.org/10.1590/S0102-33062004000300006

INSTITUTO BRASILEIRO DE ADMINISTRAÇÃO MUNICIPAL - IBAM. Manual de gerenciamento integrado de resíduos sólidos. Rio de Janeiro, 2001. Available in: http://www.resol.com.br/cartilha4/manual.pdf. Access: 21 Mar. 2018. 
IBGE. Diretoria de Pesquisas. Coordenação de População e Indicadores Sociais. Estimativas da população residente: Ivoti. 2017. Available in: https://cidades.ibge.gov.br/brasil/rs/ivoti/panorama Access: 20 Apr. 2018.

JIANG, Z.; QIN, R.; ZHANG, H. H.; ZOU, J. H.; SHI, Q. Y.; WANG, J. R.; JIANG, W. S.; LIU, D. H. Determination of Pb genotoxic effects in Allium cepa root cells by fluorescent probe, microtubular immunofluorescence and comet assay. Plant Soil, v. 383, n. 1-2, p. 357-372, 2014. https://doi.org/10.1007/s11104-014-2183-9

KABATA-PENDIAS, A. Trace elements in soil and plants. 4. ed. New York: Taylor and Francis Group, 2011. 505 p.

KIELING-RUBIO, M. A.; BENVENUTI, T.; COSTA, G. M.; PETRY, C. T.; RODRIGUES, M. A. S.; SCHMITT, J. L.; DROSTE, A. Integrated environmental assessment of streams in the Sinos River basin in the state of Rio Grande do Sul, Brazil. Brazilian Journal of Biology, v. 75, n. 2, suppl., p. 105-113, 2015. http://dx.doi.org/10.1590/1519-6984.1013

KLAUCK, C. R.; RODRIGUES, M. A. S.; SILVA, L. B. Evaluation of phytotoxicity of municipal landfill leachate before and after biological treatment. Brazilian Journal of Biology, São Carlos, v. 75, n. 2, p. 57-62, 2015. https://dx.doi.org/10.1590/15196984.1813

KWASNIEWSKA, J.; NALECZ-JAWESKI, G.; SKRZYPCZAK, A.; PLAZA, G. A.; MATEJCZYK, M. An assessment of the genotoxic effects of landfill leachates using bacterial and plant tests. Ecotoxicology and Environmental Safety, v. 75, p. 55-62, 2012. https://doi.org/10.1016/j.ecoenv.2011.08.020

LAMHAMDI, M.; BAKRIM, A.; AARAB, A.; LAFONT, R.; SAYAH, F. Lead phytotoxicity on wheat (Triticum aestivum L.) seed germination and seedlings growth. Comptes $\begin{array}{lllllll}\text { Rendus Biologies, } & \text { v. } 334, \quad \text { n. } 2, \quad \text { p. 118-126, }\end{array}$ https://doi.org/10.1016/j.crvi.2010.12.006

LEME, D. M.; MARIN-MORALES, M. A. Allium cepa test in environmental monitoring: A review on its application. Mutation Research, v. 682, p. 71-81, 2009. https://doi.org/10.1016/j.mrrev.2009.06.002

MORAES, C. L.; MARINI, P.; FERNANDO, J. A.; MORAES, D. M.; CASTRO, L. A. S.; LOPES, F. N. Alterações fisiológicas e ultraestruturais de plântulas de tomate induzidas por chumbo. Revista Iheringia, v. 69, n. 2, p. 313-322, 2014.

POURRUT, B.; JEAN, S.; SILVESTRE, J.; PINELLI, E. Lead-induced DNA damage in Vicia faba root cells: potential involvement of oxidative stress. Mutation Research, v. 726, n. 2, p. 123-128, 2011. https://dx.doi.org/10.1016/j.mrgentox.2011.09.001

RENOU S.; GIVAUDAN, J. G.; DIRASSOUYAN, F.; MOULIN, P. Landfill leachate treatment: review and opportunity. Journal of Hazardous Materials, v. 150, p. 468-493, 2008. https://doi.org/10.1016/j.jhazmat.2007.09.077

RIGUETTI, F. P.; CARDOSO, C. A. L.; CAVAlHEIRO, A. A.; LENZI, E.; FIORUCCI, A. R.; SILVA, M. S. Manganês, zinco, cádmio, chumbo, mercúrio e crômio no chorume de aterro sanitário em Dourados, MS, Brasil. Revista Ambiente \& Água, v. 10, n. 1, p. 153 163, 2015. http://dx.doi.org/10.4136/ambi-agua.1538 
RODRIGUES, L. C. A.; BARBOSA, S.; PAZIN, M.; MASELlI, B. S.; BEIJO, L. A.; KUMMROW, F. Fitotoxicidade e citogenotoxicidade da água e sedimento de córrego urbano em bioensaio com Lactuca sativa. Revista Brasileira de Engenharia Agrícola e Ambiental, v. 1 17, n. 10, p. 1099-1108, 2013.

ROSA, B. P.; PAULA, B. C. L.; COLEONE, E. S. A.; CAMPOS, F. Impactos causados em cursos d'água por aterros controlados desativados no Município de São Paulo, Sudeste do Brasil. Revista Brasileira de Gestão e Sustentabilidade, v. 4, n. 7, p. 63-76, 2017. https://dx.doi.org/10.21438/rbgas.040707

SILVA, A. S.; RIBEIRO, L. S.; PAIVA, W.; MELO, M. C.; MONTEIRO, V. E. D. Avaliação do potencial tóxico dos resíduos sólidos urbanos da cidade de Campina Grande - PB. Revista Matéria, v. 20, n. 4, p. 840-851, 2015.

SOLID WASTE ASSOCIATION OF NORTH AMERICA - SWANA. Leachate generation, collection and treatment at municipal solid waste disposal facilities. Silver Spring, 1997.

WANG, H.; GUANGRONG, Z.; GUOQING, S.; FANGTING, P. Toxicity of $\mathrm{Cu}, \mathrm{Pb}$ and $\mathrm{Zn}$ on seed germination and young seedlings of wheat (Triticum aestivum L.). In: COMPUTER AND COMPUTING TECHNOLOGIES IN AGRICULTURE, 5., 2011, Beijing, China. Proceedings[...] Berlin: Springer, 2011. p. 231-240.

YANG, N.; DAMGAARD, A.; LÜ, F.; SHAO, L. M.; BROGAARD, L. K. S.; HE, P. J. Environmental impact assessment on the construction and operation of municipal solid waste sanitary landfills in developing countries: China case study. Waste Management, v. 34, p. 929-937, 2014. https://doi.org/10.1016/j.wasman.2014.02.017 